EESTI NSV TEADUSTE AKADEEMIA TOIMETISED. VIII KOIDE

BIOLOOGILINE SEERIA. 1959, NR. 3

ИЗВЕСТИЯ АКАДЕМИИ НАУК ЭСТОНСКОИ ССР. ТОМ VІІ

СЕРИЯ БИОЛОГИЧЕСКАЯ. 1959, 스 3

\title{
О ВЗАИМООТНОШЕНИЯХ АЗОТОБАКТЕРА С CLOSTRIDIUM PASTEURIANUM В ПОЧВЕННЫХ УСЛОВИЯХ
}

\author{
Р. С. ГОЛОВАЧЕВА
}

Взаимоотношения азотобактера с Clostridium pasteurianum привлекали внимание целого ряда исследователей. Уже в первые годы изучения азотфиксирующих микроорганизмов отмечалась жизненность ассо! иаций аэробных и анаэробных азотфиксаторов $[1,19-21]$.

Эксперименты ряда авторов $[2,9,16,17,22,23]$ показали, что эффективность усвоения молекулярного азота азотобактером и клостридиумом в смешанных культурах выше, чем в монокультурах.

При выращивании таких сельскохозяйственных культур, как овес [14], просо и пшеница $\left[{ }^{2}\right]$, капуста и помидоры $\left[{ }^{4}\right]$ совместное применение азотфиксаторов оказало также более сильное влияние на урожайность, чем раздельное.

Одна из основных причин высокой эффективности азотфиксации в совместных культурах азотобактера и клостридиума заключается в том, что энергетическое вещество среды в силу некоторой противоположности свойств азотфиксаторов расходуется наиболее экономно $[9,16]$. Азотобактер способен использовать в виде солей продукты метаболизма клостридиума - уксусную и масляную кислоты, в то же время слизь, вырабатываемая азотобактером и покрывающая его клетки, может служить прекрасным энергетическим материалом для маслянокислого брожения.

Установлено, что в смешанных культурах азотобактера и клостридиума стимулируется энергия размножения обоих микроорганизмов $[2,15-17]$.

Однако, как показывают некоторые наблюдения, взаимное благоприятное влияние азотфиксаторов имеет место лишь при определенных дозировках посевного материала $\left[{ }^{16}\right]$.

То, что соотношение азотобактера и клостридиума в почве имеет большое значение с точки зрения эффективности азотфиксации подчеркивается также в работе [6].

Ко всему вышеизложенному имеет непосредственное отношение вопрос о сравнительной эффективности почвенного и агарового азотобактерина.

По наблюдениям ряда авторов, почвенный азотобактерин эффективнее агарового [3, 8, 18 и др.]. Причину этого названные исследователи видят в том, что азотобактер, вследствие длительного культивирования на агаровых средах, теряет приспособленность к существованию в почвенных условиях, в связи с чем при внесении в почву значительная часть его погибает.

Нам кажется, что такое объяснение не может быть исчерпывающим. Как ни странно, но до настоящего времени микробиологами полностью игнорировался факт присутствия в почвенных препаратах азотобактера другого азотфиксатора - клостридиума, развитие которого в этих пре- 
паратах неизбежно, поскольку готовятся они на нестерильной почве. На интенсивное же развитие клостридиума в почвенном азотобактерине указывалось уже ранее $[10,11]$.

Возникает вопрос, не является ли одной из основных причин более высокой эффективности почвенного азотобактерина по сравнению с агаровым то обстоятельство, что в почвенном азотобактерине, наряду с азотобактером, развивается и клостридиум.

С целью выяснения степени развития клостридиума в почвенном азотобактерине, приготовленном различными способами, а также для того, чтобы исследовать характер взаимоотношений обоих азотфиксаторов в почвенных препаратах, нами были проведены соответствующие опыты, описание которых приводится в настоящей работе.

Опыт 1. проводился в невысоких, плоских $(60 \times 50 \times 12$ см) ящиках, каждый из которых был наполнен 12 кг просеянной через частое сито полевой дерново-карбонатной почвы, в которую было внесено $0,02 \%$ $\mathrm{KH}_{2} \mathrm{PO}_{4}$. Содержание общего азота в почве составляло 0,265\%. Опыт состоял из двух серий, различавшихся тем, что в одном случае в почву было добавлено $2 \%$ сахара, а в другом нет. Азотобактер предварительно выращивался на агаровой среде Әшби, клостридиум - в высоком слое жидкой среды Виноградского. Қлостридиум применялся в виде накопительной культуры, полученной путем многократных пересевов на элективную среду. Обе серии опыта имели следующие варианты: контроль (без внесения азотфиксаторов), клостридиум, клостридиум + азотобактер, азотобактер. Опыт проводился при комнатной температуре, длительность его равнялась 39 дням. С целью равномерного распределения азотфиксаторов по всему почвенному слою и усиления развития азотобактера почва во всех опытах ежедневно тщательно перемешивалась. Во избежание чрезмерно быстрого высыхания земли и попадания в нее пыли ящики покрывались стеклами. Для поддержания равномерной влажчости почва в ящиках периодически увлажнялась. Почвенные пробы для микробиологических анализов брались после тщательного перемешивания. Результаты микробиологических наблюдений приведены в табл. 1.

Приведенные в этой таблице данные указывают прежде всего на то, что по динамике развития азотфиксаторы резко различались между собой. В то время как азотобактер развивался наиболее интенсивно в начальный период, клостридиум, как спороносный организм, отставал от него в своем развитии и в большинстве случаев достигал максимума лишь к концу опыта.Медленное размножение клостридиума по сравнению с азотобактером объясняется еще и тем, что исходное его содержание было во много раз ниже содержания азотобактера в соответствующих вариантах.

При внесении азотобактера в почву без добавления сахара наступало быстрое отмирание его клеток вследствие недостатка углеводов. Добавление сахара резко стимулировало развитие не только внесенного, но и спонтанного азотобактера.

Клостридиум также реагировал на добавление сахара интенсивным развитием, хотя и значительно более слабым, чем азотобактер.

Интересно отметить, что во всех вариантах серии без добавления сахара, в том числе и в контроле, численность клостридиума к моменту окончания опыта возросла. По-видимому, чрезвычайно низкое его исходное содержание в почве было обусловлено недостатком влаги и в какойто мере менее благоприятными температурными условиями, так как использовавшаяся в опыте почва в течение длительного периода хранилась 


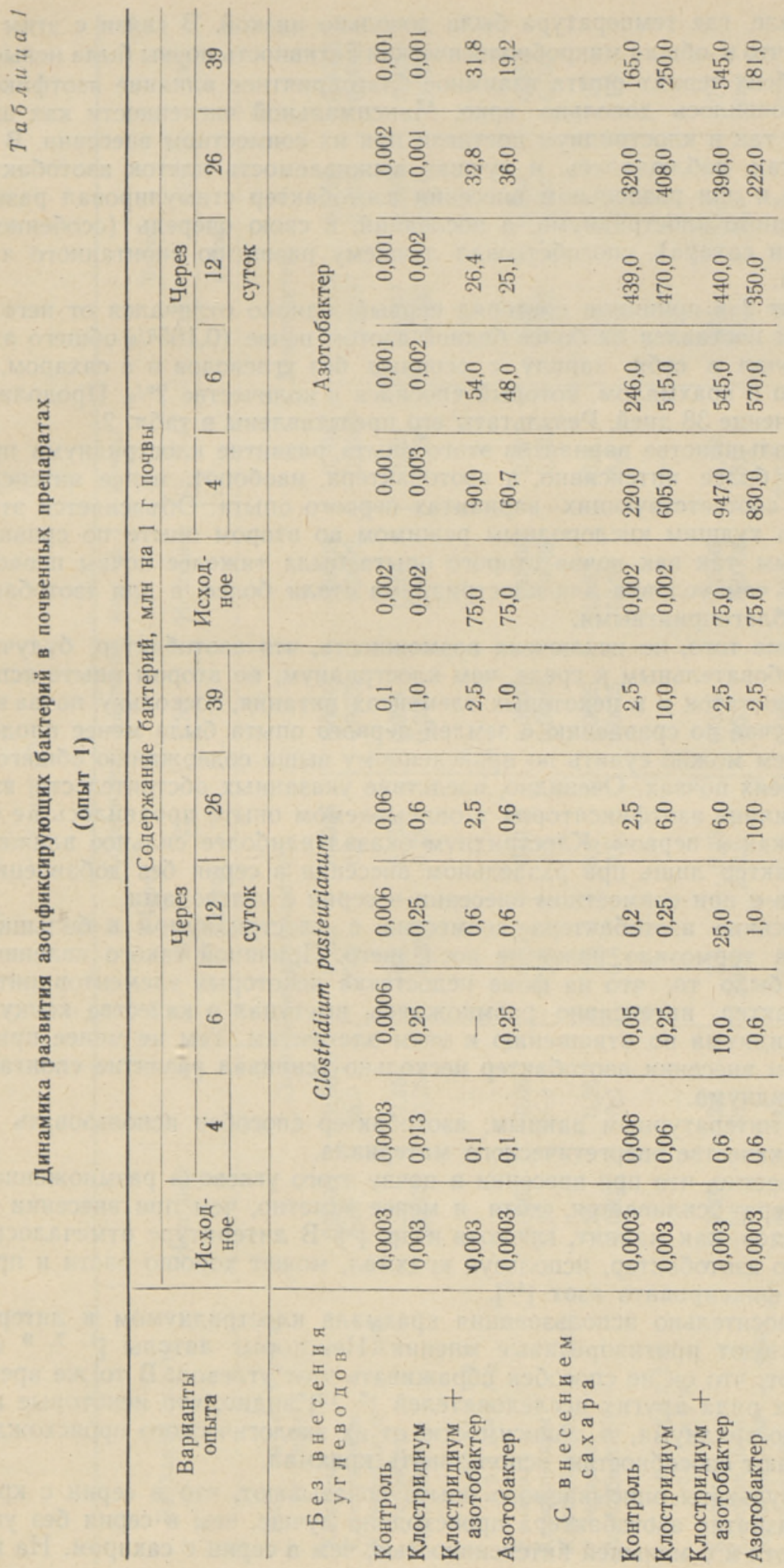


в подвале, где температура была довольно низкой. В связи с этим возможно, что и общая микробиологическая активность почвы была невысока.

В обеих сериях опыта взаимное благоприятное влияние азотфиксаторов проявилось довольно ярко. Максимальной численности как азотобактер, так и клостридиум достигли при их совместном внесении. В этих вариантах наблюдалась и лучшая выживаемость клеток азотобактера. Однако и при раздельном внесении азотобактер стимулировал развитие спонтанного клостридиума, а последний, в свою очередь (особенно при внесении сахара), способствовал лучшему развитию спонтанного азотобактера.

Опыт 2 в принципе повторял первый, однако отличался от него тем, что был поставлен на более бедной азотом почве $(0,165 \%$ общего азота) и включал в себя, наряду с сериями без углеводов и с сахаром, еще и серию с крахмалом. который вносился в количестве $2 \%$. Продолжался он в течение 38 дней. Результаты его представлены в табл. 2.

В большинстве вариантов этого опыта развитие клостридиума происходило более интенсивно, а азотобактера, наоборот, менее интенсивно, чем в соответствуюших вариантах первого опыта. Объясняется это несколько худшим кислородным режимом во втором опыте по сравнению с первым, так как почва второго опыта была тяжелее почвы первого, в связи с чем условия для клостридиума стали более, а для азотобактера менее благоприятными.

Кроме того, не исключена возможность, что азотобактер, будучи более требовательным к среде, чем клостридиум, во втором опыте испытывал недостаток и в некоторых элементах питания, поскольку почва в данном случае по сравнению с землей первого опыта была менее плодородна, о чем можно судить по приведенному выше содержанию общего азота в обеих почвах. Очевидно, вледствие указанных обстоятельств, взаимное влияние азотфиксаторов в описываемом опыте проявилось не столь четко, как в первом. Клостридиум оказал наиболее сильное влияние на азотобактер лишь при раздельном внесении в серии без добавления углеводов и при совместном внесении в серии с углеводами.

Внесение азотобактера совместно с клостридиумом в большинстве случаев тормозило развитие последнего. Причиной такого явления, видимо, было то, что на фоне недостатка некоторых элементов питания, азотобактер, интенсивно размножаясь, выступал в качестве конкурента клостридиума по отношению к этим элементам. Тем не менее при раздельном внесении азотобактер несколько усиливал развитие спонтанного клостридиума.

По литературным данным, азотобактер способен использовать крахмал в качестве энергетического материала.

Известно, что при внесении в почву этого углевода размножение азотобактера усиливается, хотя и менее заметно, чем при внесении таких углеводов, как маннит, глюкоза и др. $\left.{ }^{1}\right]$. В литературе отмечалось также, что азотобактер, используя крахмал, может хорошо расти и продуктивно фиксировать азот [10].

Относительно использования крахмала клостридиумом в литературе суцествуют противоречивые мнения. Некоторые авторы [1, 7. 9 и др.] считают, что он не способен сбраживать этот углевод. В то же время из данных ряда других исследователей $\left[{ }^{5,12}\right]$ видно, что некоторые штаммы клостридиума, в зависимости от их экологического происхождения, обладают способностью использовать крахмал.

Результаты описываемого опыта показывают, что в серии с крахмалом развитие азотобактера происходило лучше, чем в серии без углеводов, хотя и с меньшей интенсивностью, чем в серии с сахаром. На клост- 


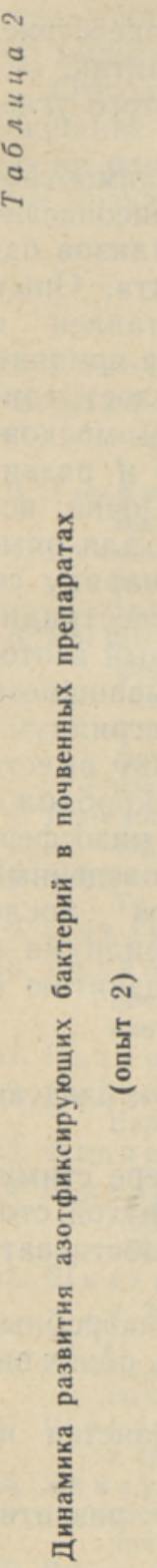

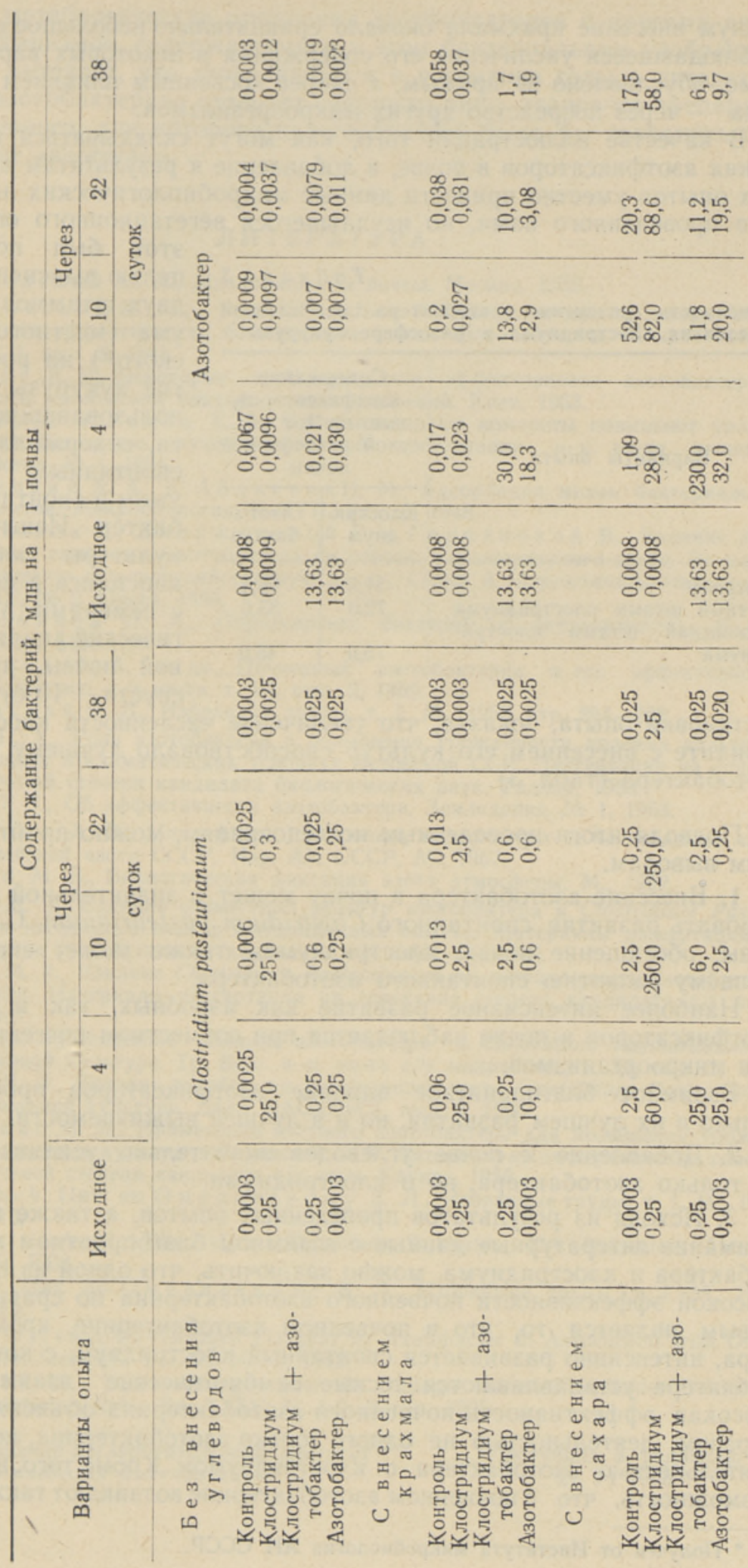


ридиум внесение крахмала оказало сравнительно небольшое воздействие. Наблюдавшееся увеличение его содержания в некоторых вариантах, видимо, обусловлено не прямым, а скорее косвенным влиянием этого углевода - через посредство других микроорганизмов.

В качестве иллюстрации того, как могут складываться взаимоотношения азотфиксаторов в почве, в добавление к результатам вышеописанных опытов уместно привести данные микробиологических анализов одного проведенного нами, но неудавшегося вегетационного опыта. Опыт

та ал иц а 3

Зависимость развития азотобактера от степени развития клостридиума в ризосфере кукурузы

Содержание азотфиксаторов, тыс. на 1 г абс. Варианты опыта сухой ризосферной почвы

\begin{tabular}{|c|c|c|c|}
\hline & \\
\hline & & $\begin{array}{c}\text { Клостри- } \\
\text { днум }\end{array}$ & $\begin{array}{l}\text { Азото- } \\
\text { бактер }\end{array}$ \\
\hline $\begin{array}{l}\text { Контроль } \\
\text { Местный штамм }\end{array}$ & м клостридиума & $\begin{array}{l}31,5 \\
72,0\end{array}$ & $\begin{array}{l}16,4 \\
33,6\end{array}$ \\
\hline $\begin{array}{l}\text { Московский ш } \\
\text { диума }\end{array}$ & Ітамм клостри- & 75,0 & 45,0 \\
\hline
\end{tabular}
этот был поставлен с целью выяснения влияния двух штаммов клостридиума (местного и московского*) на рост и развитие кукурузы. Почва, использовавшаяся для опыта, содержала наряду со спонтанным клостридиумом и спонтанный азотобактер. Испытывавшиеся культуры клостридиума вносились в почву вместе с семенами. Микробиологический анализ ризосферной почвы, проведенный спустя 10 суток после постановки опыта, показал, что увеличение численности клостридиума в варианте с внесением его культур способствовало лучшему развитию и азотобактера (табл. 3).

Подводя итоги проведенным исследованиям, можно прийти к следующим выводам.

1. Внесение азотобактера в почву может в значительной мере стимулировать развитие спонтанного Clostridium pasteurianum. С другой стороны, обогащение почвы клостридиумом также может способствовать лучшему развитию спонтанного азотобактера.

Наиболее интенсивное развитие как аэробных, так и анаэробных азотфиксаторов в почве наблюдается при совместном внесении обоих видов микроорганизмов.

Взаимное благоприятное влияние азотфиксаторов проявляется не только в их лучшем развитии, но и в лучшей выживаемости.

2. Добавление к почве углеводов значительно усиливает развитие не только азотобактера, но и клостридиума.

3. Исходя из результатов проведенных опытов, а также принимая во внимание литературные данные о взаимном благоприятном влиянии азотобактера и клостридиума, можно заключить, что одной из причин более высокой эффективности почвенного азотобактерина по сравнению с агаровым является то, что в почвенном азотобактерине, кроме азотобактера, интенсивно развивается спонтанный клостридиум, с которым у азотобактера устанавливаются тесные симбиотические взаимоотношения. Высокая эффективность почвенного азотобактерина объясняется, таким образом, деятельностью не одного только азотобактерина, но совместной леятельностью азотобактера с клостридиумом. Кроме того, не исключена возможность, что в почвенном азотобактерине возникают также симбиоти-

\footnotetext{
* Получен от Института микробнологии АН СССР.
} 
ческие или метабиотические отношения азотфиксаторов с другими видами микроорганизмов, содержащимися в этом бактериальном удобрении.

Отсюда вытекает, что утвердившееся в последние годы в литературе название «азотобактерин» отвечает сущности лишь агарового препарата, но не почвенного, для которого целесообразнее было бы сохранить старое название «азотоген».

\section{ЛИ ТЕРАТ У РА}

1. В и н огр адски й С. Н., Микробиология почвы. Москва, 1952.

2. В озняко в ск ая Ю. М., Роль Clostridium Pasteurianum как фактора, повышающего эффективность бактеризации семян азотобактером. Микробиология, т. XVII, вып. $5,1948$.

3. Г ерб ард т А. Г., Некоторые пути повышения эффективности азотобактерина. Вопросы применения бактериальных удобрений. Киев, 1953.

4. Гу сев M. И. и Р емп е Е. Х., Бактеризованные компосты повышают урожай овощей. Бюллетень научно-технической информации н.-и. ин-та овощного хозяйства, № $1,1956$.

5. И мшене цки й А. А. и Абди е вич Н. М., Адсорбация мелом бактериальных ферментов. Микробиология, т. XVII, вып. 6, 1948.

6. Цит. по Новак Б., Дворжаковой Г. и Горчаковой Я., Влияние естественных симбиозов азотобактера на усвоение молекулярного азота. За социалистическую сельскохозяйственную науку, Серия А. Агрономия-зоотехния, год изд. IV, № 2. Прага, 1955.

7. Красильников Н. А., Определитель бактернй и актиномнцетов. М.-Л., 1949, стр. 649.

8. О 6 р а з ц о в а А. А. и др., Почвенный азотобактерин и его эффективность. Тр. Горьковск. с/'х ин-та, т. VI, вып. 2, 1950.

9. О ме л ян с к и й В. Л., Избранные труды, т. І. М., 1953, стр, 294-322.

10. Р а хно П. Х., Роль азотобактера в повышении урожайности полевых культур в почвенных и климатических условиях Эстонской ССР. Диссертация на соискание ученой степени кандидата биологических наук. Таллин, 1953.

11. Р а х н о П. Х., Об эффективности азотобактера. Земледелие, № 1, 1953.

12. Р ы б а лкин н А. В., Микрофлора тундровых, подзолистых и черноземных почв Европейской части СССР. Изд. АН СССР, М., 1957.

13. Ф едо ро в М. В., Биологическая фнксация азота атмосферы. М., 1952.

14. Ш кля р М. 3., Влияние совместных культур азотобактера и Clostridium Pasteurianum на урожай овса в вегетационных опытах. Материалы диссертации на соискание ученой степени кандидата $\mathrm{c} / \mathrm{x}$ наук. Л., 1947.

15. Ш к л я р M. 3., Влияние Clostridium Pasteurianum на сохраняемость азотобактера в торфе. Материалы диссертации на соискание степени кандидата $\mathrm{c} / \mathrm{x}$ наук. Л.. 1947.

16. Шкля р M. 3., Взаимное влияние азотобактера и Clostridium Pasteurianum в смешанной культуре. Тр. Всес. н.-н. ин-та с/'х микробиол., т. ХI, вып. 2, 1951.

17. Шкл я р M. 3., Влияние аэробов на жизнедеятельность Clostridium Pasteurianum в смешанной культуре. Докл. ВАСХНИЛ, вып. 8, 1956.

18. Я н к ауск а с И. И., Применение местного азотобактера для повышения урожайности полевых культур в Литовской ССР. Автореферат диссертации на соискание ученой степени кандидата $\mathrm{c} / \mathrm{x}$ наук. Каунас, 1956.

19. В е i jerinck. Цит. по О мелянскому В. Л., Избранные труды, т. I, М., 1953, cтp. 315 .

20. Freudenreich, E., Ober stickstoffbindende Bakterien, Zbl. Bakteriol., Abt: II, Bd. 10, 1903.

21. Krueger. Цит. по Омелянскому В. Л., Избранные труды, т. I, М., 1953, cтp. 315.

22. L in d, C., Wils o n, P., Nitrogen Fixation by Azotobacter in Association with Other Bacteria. Soil Sci., Vol. 54, No. 2, 1942.

23. W a rmbold, H., Untersuchungen über die Biologie stickstoffbindender Bakterien. Landwirtsch. Jahrb., Bd. XXXV, H. 1,2. Berlin, 1906. 


\section{AZOTOBAKTERI JA CLOSTRIDIUM PASTEURIANUM'I VAHELISTEST} SUHETEST MULLAS

\section{R. Golovatšova}

\section{Resümee}

Kahe tähtsama ōhulämmastikku siduva mullabakteri, aeroobse azotobakteri ja anaeroobse Clostridium pasteurianum' $\mathrm{i}$ vaheliste suhete uurimisega on tegelnud rida mikrobiolooge. Nende poolt avaldatud andmete kohaselt mōjutavad kōnesolevad bakteriliigid soodustavalt vastastikust arengut ja ōhulämmastiku sidumist. Samuti on olemasolevail andmeil steriliseerimata mullast valmistatud azotobakteri preparaadid pöllukultuuride väetamisel efektiivsemad kui steriilsel agarsöötmel paljundatud azotobakteri puhaskultuur, nn. agar-azotobakteriin.

Käesolevas töôs esitatud katsetulemused näitavad, et mōlema eespool nimetatud nähtuse vahel on kindel side. Uhtıasi on vōimalik teha järeldusi, nimelt:

1. Azotobakteri kultuuri lisamine mulda soodustab tunduval määral spontaanse Clostridium pasteurianum'i arengut ja vastupidi.

Kōige intensiivsem on aeroobsete ja anaeroobsete ōhulämmastikku siduvate bakterite areng mullas siis, kui viia sinna mōlema liigi kultuure.

Nimetatud bakterite vastastikune soodustav mōju ilmneb nii nende paremas arengus kui ka paremas säilimises.

2. Süsivesikute lisamine mulda soodustab tunduvalt mitte ainult azotobakteri, vaid ka Clostridium'i arengut.

3. Nii meie katsete kui ka kirjanduses ilmunud seisukohtade pōhjal vōib teha järelduse, et azotobakteri mullapreparaatide kōrge efektiivsus, vōrreldes tema agarpreparaatiuega, on tingitud spontaansest Clostridium ist, mis azotobakteri kõrval areneb intensiivselt mullapreparaatides.

Vastavalt seliele vōib viimastel aastatel kirjanduses levinud nimetust «azotobakteriin» pidada sobivaks vaid azotobakteri agarpreparaatidele, mitte aga mullapreparaatidele, mida ka edaspidi oleks otstarbekam nimetada endiselt «azotogeeniks».

\section{Eesti Maaviljeluse Instituut}

Saabus toimetusse

21. VI 1958

\section{THE INTERCONNECTIONS OF THE AZOTOBACTER AND THE CLUSIRIDIUM FASTEURIANUM IN THE SOIL}

\section{R. Golovachova}

\section{Summary}

A number of biologists have dealt with the interconnections of the two most important nitrogen fixing bacteria, the aerobic Azotobacter and the anaerobic Clostridium pasteurianum. According to the availabie data, the above species of bacteria mutually stımulate their development as well as the fixation of nitrogen. On the basis of these data it has been proved that the Azotobacter preparations made of unsterilized soil are more effective as fertilizers of field cultures than the pure cultures of Azotobacter on sterile agar, the so-called Azotobacterin.

The results of experiments presented in this article show that both above phenomena are closely associated. At the same time they give the possibility of drawing the following conclusions:

1. The introduction of the culture of Azotobacter into the soil stimulates, to a great extent, the development of the spontaneous Clostridium pasteurianum, and vice versa.

Most intensive is the development of the aerobic and anaerobic nitrogen fixers in the soil in case of introduction of both of these bacteria into the soil.

The mutually stimulating influence of the above bacteria becomes apparent in their improved development as well as in their better preservation.

2. The addition of carbohydrates to the soil intluences to a better advantage not only the development of the Azotobacter, but also that of the Clostridium pasteurianum.

3 . The results of our own experiments, as well as the opinions expressed in the publications on that subject allow us to draw the conclusion that the high efficiency or the Azotobacter soil preparations, if compared to the agar preparations (of the same micioorganisms) is due to the spontaneous Clostridium pasteurianum that develops intensively at the side of the Azotobacter in soil preparations.

In accordance with the above facts, the term «Azotobacterin», widely spread in the literature of the recent years, may be regarded as suitable only if applied to the agar preparations of the Azotobacter, and not to soil preparations which ought to be named «Azotogen», as before.

The Estonian Scientific Research Institute of Agriculture and Melioration 